\title{
THE EFFECT OF CORPORATE GOVERNANCE AND CREDIT RISK TOWARD LIQUIDITY AND PROFITABILITY ON BANKING LISTED IN INDONESIA STOCK EXCHANGE IN 2012-2016
}

\author{
Nurtrontong Pitoyo, Suhadak, Rahayu Sri Mangesti, Handayani Siti Ragil \\ Faculty of Administrative Science, University of Brawijaya, Malang, Indonesia \\ *E-mail: abu.nabilasalsa@gmail.com
}

\begin{abstract}
The purpose of this research is to study and explain the effect of corporate governance and credit risk on liquidity and profitability on banking in Indonesia. This study used Generalized Structured Component Analysis (GSCA) to measure the effect of corporate governance and credit risk towards liquidity and profitability. The result of this research showed that the corporate governance has an effect towards liquidity and profitability, the credit risk has an effect towards liquidity and profitability, and the last, the liquidity has an effect on profitability
\end{abstract}

\section{KEY WORDS}

Corporate governance, credit risk, liquidity, profitability, conventional banking.

The Asian Development Bank identified the origins of the economic crisis in Asia, including Indonesia were the lack of implementation of corporate governance, including banking governance (Zhuang, et.al, 2001). This forced many banks to be liquidated. As a follow up, Bank Indonesia regulated the banking governance in Indonesia by passing the regulation regard Corporate Governance and Risk Management (PBI no.4/8/PBI/2006 dan $\mathrm{PBI}$ no.5/8/PBI/2003) by creating a sound and strong banking system. However, does the existence of these regulations are able to realize the achievement of sound and strong banking? This compels further investigation in Indonesian banks for both the conventional and sharia systems. This question initiated researcher to examine the effect of Corporate Governance and Credit Risk toward Liquidity and Profitability on the conventional banking after the enactment of these regulations. Previous researchers have shown different results, such as the research by Florinita (2014), Abogun et al. (2014), Inam and Mukhtar (2014), which showed that corporate governance has a positive effect on Liquidity, in contrast other researchs show different results, such as Delis et al. (2009) and Rajangan et al. (2014). Corporate governance has a positive affect on profitability as was exposed by other researchers such as Aggarwal (2013), Ghaffar (2014), and Todorovic (2013), however other studies show differing results, such as Omoniyi et al. (2013), and Rashid et al. (2010).

Credit risk affects negatively on liquidity as had been revealed by researchers such as Gautam (2016), Megeid (2013), and Alzoubi (2017), while different research showed by Murage and Muiru (2016) and Vodova (2012). Moreover, credit risk affects negatively on profitability as revealed by researchers such as Poudel (2012), Lata (2014), and Kodithuwakku (2015), while the different results showed by Olausi dan Abiola (2014) and Sutrisno (2016). Liquidity has a positive effect on profitability as was showed by Khan dan Ali (2016), Oluwasegun dan Samuel (2015), Ibrahim (2017), while different research as revealed by Nimer et al. (2015 and Dahiyat et al. (2016).

The debate on the result of previous studies about the effect of corporate governance on liquidity and profitability, the effect of credit risk on liquidity on profitability, and the effect of liquidity on profitability also motivated researcher to reexamine the arguments about the impat of corporate governance and credit risk toward liquidity and profitability.

\section{LITERATURE REVIEW}

Cadbury Committe (1992) defines corporate governance as the system by which companies are directed and controlled. $\operatorname{OECD}(2015,2004)$ defines corporate governance as 
system which involves a set of relationships between a company's management, its board, its shareholders and other stakeholders. Corporate governance also provides the structure through which the objectives of the company are set, and the means of attaining those objectives and monitoring performance are determined. Through Corporate Governance, the performance of bank is expected to be achieved. Some researchers showed that Corporate Governance can affect on performance. Todorovic, (2013) stated that companies with higher level of implementation of principles of corporate governance and better practice of corporate governance are more profitable and have better performance. Inam and Mukhtar, (2014) stated that Corporate governance is positively associated with profitability and liqudity. Adi et al. (20120) stated that the better corporate governance will improve financial performance.

Credit risk is the exposure faced by banks when a borrower (customer) defaults in honouring debt obligations on due date or at maturity (Kolapo, et al. 2012). In line with Kolapo's opinion, Brown and Moles, (2014) stated that credit risk can be defined as the potential that a contractual party will fail to meet its obligations in accordance with the agreed terms. Credit failures in banks is not new or a rare occurrence, they affect their liquidity position as well as cash flows and profits (Adeusi et al., 2013). In line with Adeusi's opinion Megeid (2013) stated that liquidity performance tends to decrease with the increase in credit risk levels. Related with profitability, that any increase in the volume of non-performing loans would reduce profitability of banks (Etale et al., 2016). Even, Alalade et al., 2014 state that bank with high credit risk has high bankruptcy risk.

Based on the explanation above, that credit risk is faced by bank can cause to decrease the bank's liqudity and profitability.

Liquidity is a key issue in the business of banking. Just as the air is fundamental to the existence of man, so also is liquidity to the survival of banks. (Abogun, 2014). Lartey et al., 2013 stated that the liquidity of a commercial bank is its ability to fund all contractual obligations as they fall due. In line with lartey's opinion, Rasul, (2013), stated that Liquidity implies availability of cash that how bank rapidly may convert its assets into cash to meet the need of short term. It is considered as life of the banks. Delis et al., 2009 stated that banks hold liquid assets for two main reasons. First, to satisfy the demand for new loans without having to recall existing loans or realize term investments such as bond holdings and, second, to meet both daily and seasonal swings in deposits so that withdrawals can be met in a timely and orderly fashion. Based on Delis's opinion, liquidity can support profit achievement through satisfying the demand for new loan. Khan and Ali, (2016) stated that there is significant positive relationship between liquidity with profitability of the banks.

Based on the explanation in the above paragraph, the liquidity is important for banks to support the achievement of profit.

Ghaffar (2014) stated that the fundamental feature which should be present in any entity to call it a business is that it should have an intention to earn profit, include banking, so that bank performance is often measured by the level of profits earned by the bank (Sutrisno, 2016). Profitability has essential means for long-term survival of banking business, because the profitability of the business showed good prospects in the future (muthaher, 2014).

The profitability of banking does not occur suddenly but through business processes run by banks, so that profitability was predicted produced from liquidity, credit risk and corporate governance.

Hypothesis:

$\mathrm{H}_{1}$ : Corporate governance $(\mathrm{X} 1)$ has influence on liquidity $(\mathrm{Y} 1)$;

$\mathrm{H}_{2}$ : Corporate governance (X1) has influence on profitability (Y2);

$\mathrm{H}_{1}$ : Credit risk $(\mathrm{X} 2)$ has influence on liquidity $(\mathrm{Y} 1)$;

$\mathrm{H}_{1}$ : Credit risk (X2) has influence on profitability $(\mathrm{Y} 2)$;

$\mathrm{H}_{1}$ : Liquidity (Y1) has influence on profitability (Y2).

\section{METHODS OF RESEARCH}

This research used explanatory research which describes the influence of the variable exogen to endogen by means of hypothesis testing and was be implemented at the banking 
sector in Indonesia with period 2012-2106. The population of this study are the conventional banks only listed in Indonesia Stock Exchange (BEI). Selection process of sample was using purposive sampling method with the number of sample are 30 conventional banks listed on $\mathrm{BEI}$ in 2012-2016. The data analysis was performed using Generalized Structured Component Analysis (GSCA). There are four variabels which be used in this research, namely Corporate Governance, Credit Risk, Liquidity, and Profitability.

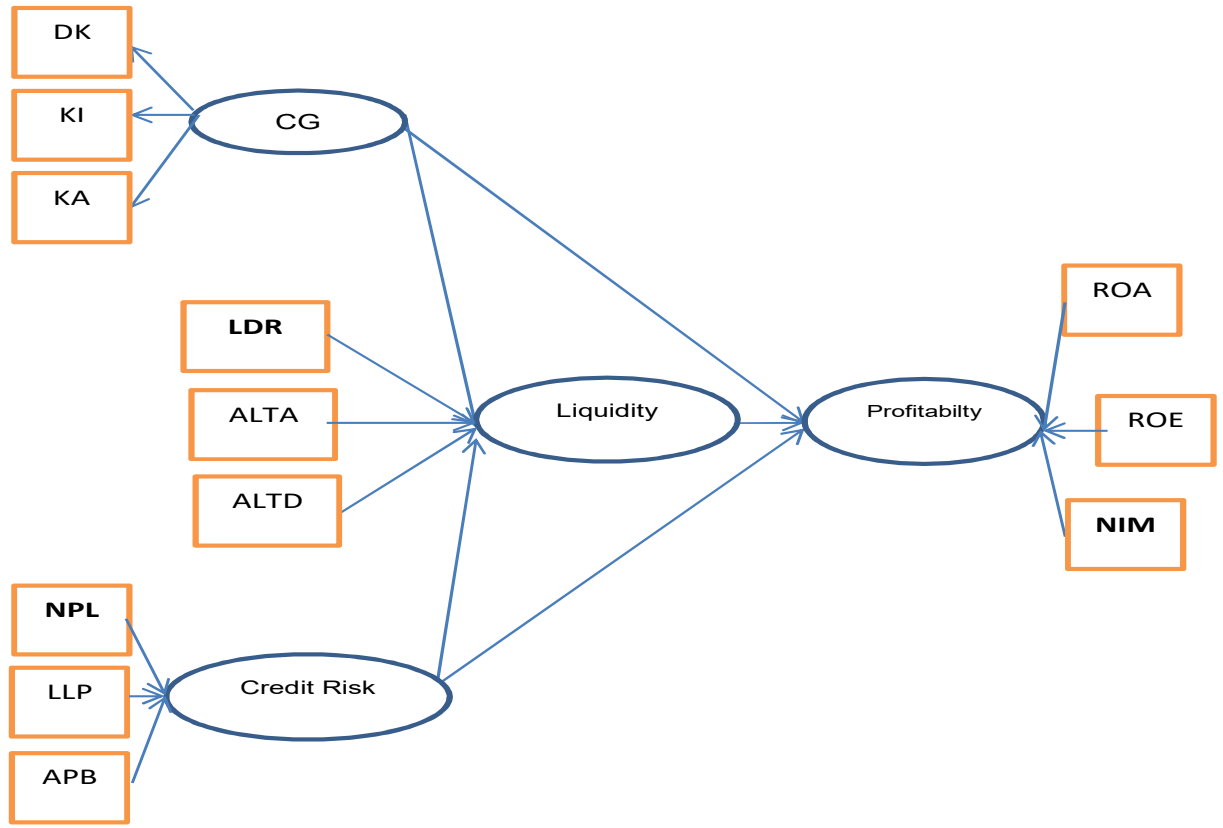

Figure 1 - Research Model

Table 1 - Variable Classification of Research Model

\begin{tabular}{|c|c|c|c|c|c|}
\hline \multirow[t]{2}{*}{ No } & \multicolumn{2}{|c|}{ Research Variable } & \multicolumn{3}{|c|}{ Indicator } \\
\hline & Variable & Notation & & Indicator Name & Label \\
\hline \multirow[t]{3}{*}{1} & \multirow[t]{3}{*}{$\begin{array}{l}\text { Corporate } \\
\text { Governance }\end{array}$} & \multirow[t]{3}{*}{$\mathrm{X} 1$} & $\mathrm{X} 1.1$ & $\begin{array}{l}\text { Dewan Komisaris (Board of } \\
\text { Commissioners) }\end{array}$ & DK \\
\hline & & & $\mathrm{X} 1.2$ & $\begin{array}{l}\text { Komisaris } \quad \text { Independen } \\
\text { (Independent Commissioners) }\end{array}$ & $\mathrm{KI}$ \\
\hline & & & $\mathrm{X} 1.3$ & Komite Audit (Audit Committe) & KA \\
\hline \multirow[t]{3}{*}{2} & \multirow[t]{3}{*}{ Credit Risk } & \multirow[t]{3}{*}{$\overline{\mathrm{X} 2}$} & $\mathbf{X 2 . 1}$ & Non Performing Loan & NPL \\
\hline & & & $\mathrm{X} 2.2$ & Loan Loss Provision & LLP \\
\hline & & & $\mathrm{X} 2.3$ & $\begin{array}{l}\text { Aktiva Produktif Bermasalah } \\
\text { (Adversely Classified Asset) }\end{array}$ & APB \\
\hline \multirow[t]{3}{*}{3} & \multirow[t]{3}{*}{ Liquidity } & \multirow[t]{3}{*}{$\mathrm{Y} 1$} & Y1.1 & Loan to Deposit Ratio & LDR \\
\hline & & & $\mathrm{Y} 1.2$ & Aset Likuid to Total Aset & ALTA \\
\hline & & & Y1.3 & Aset Likuid to Total Deposit & ALTD \\
\hline \multirow[t]{3}{*}{4} & \multirow[t]{3}{*}{ Profitability } & Y2 & Y2.1 & Return on Asset & ROA \\
\hline & & & Y2.2 & Return on Equity & ROE \\
\hline & & & Y2.3 & Net Interest Margin & NIM \\
\hline
\end{tabular}

\section{RESULTS AND DISCUSSION}

Based on the output of GSCA software, the results for FIT and AFIT values can be seen in Table 1. 
Table 1 - Identification Goodness of FIT

\begin{tabular}{|c|c|c|}
\hline \multicolumn{2}{|c|}{ Model Fit } \\
\hline \multirow{2}{*}{ BUK } & FIT & 0.345 \\
\cline { 2 - 3 } & AFIT & 0.342 \\
\hline
\end{tabular}

The analysis result for BUK provide FIT value 0.345 , it means that phenomenon on the model can be described by the variables that are used (34.5\%), while the remainder $65.5 \%$ is explained by another variable that is not included in the model.

The results of identification of path coefficient of each variable can be seen in Table 2 .

Table 2 - Estimation Result and $\mathrm{P}$ value of path coefficient

\begin{tabular}{|c|c|c|c|c|c|}
\hline \multicolumn{7}{|c|}{ Path Coefficients } \\
\hline Influence & Estimate & SE & CR & P & Description \\
\hline $\mathrm{X} 1->\mathrm{Y} 1$ & 0.626 & 0.052 & $12.04^{*}$ & 0.000 & Significant \\
\hline $\mathrm{X} 1->\mathrm{Y} 2$ & 0.360 & 0.101 & $3.57^{*}$ & 0.000 & Significant \\
\hline $\mathrm{X} 2->\mathrm{Y} 1$ & 0.285 & 0.054 & $5.32^{*}$ & 0.000 & Significant \\
\hline $\mathrm{X} 2->\mathrm{Y} 2$ & -0.367 & 0.065 & $5.66^{*}$ & 0.000 & Significant \\
\hline $\mathrm{Y} 1->\mathrm{Y} 2$ & 0.132 & 0.062 & $2.12^{*}$ & 0.036 & Significant \\
\hline
\end{tabular}

The effect of corporate governance (X1) on liquidity (Y1). GSCA analysis results obtained an estimate value 0,626 and $C R$ value $12,04^{*}$ and $P$ value 0.000 with significant level of 0.05 , so hypothesis 1 which states that corporate governance has influence on liquidty is accepted. The direction of the effect is positive, it means that the more the corporate governance, the better the liqudity.

This outcome confirms previous research such as Florinita (2014), Abogun et al. (2014), Inam and Mukhtar (2014) and also supports the Agency Theory.

The effect of corporate governance (X1) on profitability (Y2). GSCA analysis results obtained an estimate value 0,360 and $C R$ value $3,57^{*}$ and $P$ value 0.000 with significant level of 0.05 , so hypothesis 2 which states that corporate governance has influence of profitability is accepted. The direction of the effect is positive, it means that the more the corporate governance, the better the profitability.

This outcome confirms previous research such as Aggarwal (2013), Ghaffar (2014), and Todorovic (2013) and also supports the Agency Theory.

The effect of credit risk (X2) on liquidity (Y1). GSCA analysis results obtained an estimate value 0,285 and $C R$ value $5,32^{*}$ and $P$ value 0.000 with significant level of 0.05 , so hypothesis 3 which states that credit risk has influence on liquidity is accepted. The direction of the effect is positive. It is an important result in this research that credit risk has a positive effect on liquidity. Credit risk should tend to decrease liquidity. This outcome doesn't confirm previous research such as Gautam (2016), Megeid (2013), and Alzoubi (2017), but confirms the findings of Murage and Muriu (2016).

The effect of credit risk (X2) on profitability (Y2). GSCA analysis results obtained an estimate value $-0,367$ and $C R$ value $5,66^{*}$ and $P$ value 0.000 with significant level of 0.05 , so hypothesis 4 which states that credit risk has influence on profitability is accepted. The direction of the effect is negative, it means that the more the credit risk, the lower the profitability.

This outcome confirms previous research such as Lata (2014), Kodithuwakku (2015), Etale et al.,(2016) and Poudel (2012).

The effect of liquidity (Y1) on profitability (Y2). GSCA analysis results obtained an estimate value 0,132 and $C R$ value $2,12^{*}$ and $P$ value 0.036 with significant level of 0.05 , so hypothesis 5 which states that liquidity has influence on profitability is accepted. The direction of the effect is positive, it means that the more the liquidity, the better the profitability.

This outcome confirms previous research such as Lata (2014), Kodithuwakku (2015), Etale et al.,(2016) and Poudel (2012). 


\section{CONCLUSION}

The results of the study indicate that corporate governance in the conventional banking has an effect on the performance of liquidity and profitability. The corporate governance mechanism can improve supervision of the performance of the Board of Directors in terms of achieving profitability. This result shows that PBI regarding GCG has been able to influence on banking performance.

The results of the study show that credit risk in the conventional banking has an effect on profitability, the better the management of credit risk will affect the increase in profitability. This reult shows that $\mathrm{PBI}$ regarding risk management has been able to influence on banking performance.

The results of the study show that liquidity has an effect on profitability. Management must be able to optimize its liquidity to support the achievement of profitability.

\section{SUGGESTIONS}

Based on result form this research, FIT values for BUK and BUS provide FIT are 0.345. It shows that phenomenon on the model can be described by the variables that are used $(34.5 \%)$, while the remainder $65.5 \%$ is explained by another variable that is not included in the model. It means there is opportunity to add another variable in order to increase possibility for obtaining the higher FIT values.

\section{REFERENCES}

1. Abogun, Segun, Temitope Olamide Fagbemi, and Bolanle Rashidat Balogun. (2014). Corporate Governance and Bank Liquidity: Evidence From Selected Banks in Nigeria. Centrepoint Journal (Humanities Edition), 16 (2).

2. Adeusi, Stephen Oluwafemi., Niyi Israel Akeke, Obawale Simeon Adebisi, Olawale Oladunjoye. (2014). Risk Management and Financial Performance of Banks in Nigeria" European Journal Of Business and Management, 6 (31).

3. Adi, Tri Wahyu Adi, Suhadak, Siti Ragil Handayani, Sri Mangesti Rahayu (2013), The Influence of Corporate Governance and Capital Structure on Risk, Financial Performance and Firm Value: A Study on the Mining Company Listed in Indonesia Stock Exchange in 2009- 2012 European Journal of Business and Management Vol.5, No.29, 2013

4. Brown, Ken, and Peter Moles. (2012). Credit Risk Management. Edinburgh Business School, Heriot-Watt University. UK.

5. Etale, Lydnon M., Peter Ego Ayunku, and E. Etale. (2016). The Impact of Non-Performing Loans and Bank Performance in Nigeria. International Journal of Humanities and Social Science Invention, 5 (4): 1-

6. Ghaffar, Aimen. (2014). Relationship of Islamic Bank's Profitability with Corporate Governance Practices." European Journal of Business and Management, 7 (17): 1-10.

7. Inam, Hifza, and Aqeel Mukhtar. (2014). Corporate Governance and Its Impact on Performance of Banking Sector in Pakistan. International Journal of Academic Research in Applied Science, 3 (2): 26-36.

8. Khan, Rizwan Ali, and Mutahhar Ali. (2016). Impact of Liquidity on Profitability of Commercial Banks in Pakistan: An Analysis on Banking Sector in Pakistan. Global Journal of Management and Business Research.

9. Kolapo, T. Funso, R. Kolade Ayeni, and M. Ojo Oke. (2012). Credit Risk and Commercial Banks Performance in Nigeria: A Panel Model Approach. Australian Journal of Business and Management Research, 2 (2): 31.

10. Lartey, Victor Curtis, Samuel Antwi, and Eric Kofi Boadi. (2013). The Relationship Between Liquidity and Profitability of Listed Bank in Ghana. International Journal of Business and Social Science, 4 (3).

11. Murage, Caroline Wambui, and Monica Wanjiru Muiru. (2016). The Effect of Credit Risk on Corporate Liquidity of Deposit Taking Microfinance Institutions. International Journal Of Business And Social Science 7 (4): 
12. Muthaher, Osmad. (2014). Analyze on The Influence of Financing Risk and Capital Adequacy to Profitability Islamic Bank in Indonesia. Journal Of Contemporary Management Sciences - JCMS Publication, 4 (1): 55 - 72.

13. Oluwasegun, A. J., Samuel , A. (2015). The Impact of Liquidity on Nigerian Bank Performance: A Dynamic Panel Approach." Journal Of African Macroeconomic Review. 5 (2): $318-324$.

14. Sutrisno. (2016). The Effects Of Financing And Risks On The Performance Of Islamic Bank: Empirical Evidence From Indonesian Islamic Bank. Business and Management Research Journal 6 (3): 29 - 36.

15. Todorovic, Igor. (2013). Impact of Corporate Governance on Performance of Companies. Montenegrin Journal Of Economics, 9 (2): 47-

16. Zhuang, Juzhong, David Edwards, and Ma Virginita A. Capulong. (2001). Corporate Governance and Finance in East Asia: a Study of Indonesia, Republic of Korea, Malaysia, Philippines and Thailand, Asian Development Bank. 